\title{
COMPARATIVE STUDY OF THE PATTERNS AND CHARACTERISTICS URBAN MORPHOLOGY IN THE OLD CITY, CASE STUDY ROAD AND BLOCK PATTERNS BENGKULU AND SINGAPORE
}

\author{
Fitrianty WARDHANI ${ }^{1}$, Samsul BAHRI
}

DOI: $10.21163 / G T \_2020.151 .34$

\begin{abstract}
:
Urban morphology is an applied science that learns about the history of the spatial patterns of a city and learns about the development of a city. The old town area of Bengkulu was an English-built city from 1719 while Singapore was a British formation city as well, due to the London Treaty agreement occurring between the two regions. This Paper aims to be a comparison study between two cities with historical linkages in terms of identifying patterns and characteristic of its city morphology. This research is quantitative descriptive research using two analytical techniques namely diachronic reading and Tipo-morphology. The indicators used to acquire patterns and characteristics of the urban morphology are Bengkulu and Singapore which are aspects of detail consisting of road and block patterns. Through this research is expected to get similarities and differences in the patterns and charactheristic the morphological of both cities. This study will provide an overview and input for the development planning of the more advanced city of Bengkulu.
\end{abstract}

Key-words: comparative studies, urban morphology, history, Bengkulu and Singapore.

\section{INTRODUCTION}

\subsection{Theory of urban morphology}

Urban morphology is "an approach in understanding the city as a geometric collection of buildings and artifacts with the configuration of the unity of certain physical spaces the product of socio-spatial changes. "Our understanding of" urban morphology "cannot be separated from the physical form of the city which is formed primarily by the physical conditions of the environment as well as the dynamic socio-economic interactions of the people. Herbert (1932) In Conzen (2003), the scope of the study of urban morphology is emphasized on the physical form of the urban environment which can be observed from its appearance which includes elements of (1) existing road system, (2) building blocks both residential and non-residential areas (trade / industry), and (3) individual buildings. Smailes (1955) emphasizes the scope of morphological studies including (1) land use, (2) street patterns and (3) building types.

Morphology means the science of form. In the urban context, Carmona et al (2003: 61) argue that morphology is the study of the forms and shapes of residential environments. Form means an observable form and is a configuration of several objects, while a shape is a geometric feature or an external shape and outline of an object. Although they have almost the same meaning, these two words (form and shape) have a different basic understanding,

\footnotetext{
${ }^{1}$ University of Bengkulu, Architecture Program Study, Bengkulu, Indonesia, fwardhani@unib.ac.id; fwardhani@unib.ac.id
} 
where the form emphasizes the form consisting of various elements and each element can be clearly observed its characteristics and visually each element is in one unit (configuration). For example: a road corridor is visually formed from a row of buildings with a certain height and arranged within a certain distance from the road border. Shape emphasizes the external form of the form, or in other words the silhouette in the context of townscape is often referred to as the skyline. A collection of objects located above the ground surface will form certain patterns (shapes), such as linear, grid, concentric, radial, cluster, and so forth.

Smailes (1955) in Yunus (1994) introduces 3 elements of city morphology, namely land use, road patterns and building types or characteristics. Meanwhile Conzen (1962) in Yunus (1994) also suggested elements similar to Smailes, namely plan, architectural style and land use.

\subsection{Morphological components}

M.G.R. Conzen considers that it is necessary to pay attention to the four components of morphology (Carmona et al., 2003), including:

\section{Land use}

Land uses (land uses) is a principal component in the growth of the region. This component is considered as an activity system generator which determines the pattern and direction of regional growth (Kaiser, 1995). This component has

the level of temporality is very high in terms of being able to easily change literature, especially in relation to the economic value it holds. Land use greatly influences the physical appearance of the area, especially in determining the development of built and non-built areas.

Several studies and literature explain how the level of mixing (land use) mixture greatly affects the vitality of the region, economic value and several other environmental quality components (Choi and Sayyar, 2012; Barton et al, 2003: 194).

\section{Building structure}

This component is a representation of typology in morphological analysis and can be discussed in two aspects, including mass structuring and building architecture. The structuring of the masses is related to how buildings are scattered within the site along with their density and intensity while building architecture is more a physical manifestation of spaces and buildings that represent the culture, history and creativity of a community.

\section{Pattern}

This component can be discussed in terms of size (dimensions) and distribution. The size of the plot will affect the intensity of land use while the distribution of the plot will affect the establishment of a connecting network. In general, the pattern of this plot is strongly influenced by natural potential, especially contours and geological conditions. Legally, the plot is limited by ownership boundaries which greatly affect the pattern of control, use and management of space.

\section{Road network}

This component is a derivative function of land use. As a connecting line, the road network greatly affects the efficiency and effectiveness of regional functions. The road network as a representation of public space is considered as the core generator of the vitality of the region as explained. 
There are three types of street pattern, namely (summarized from Northam, 1975): a. Irregular street pattern (irregular system). Any irregularity home placement and lanes in either direction and width. This pattern was seen in the early growth of cities but at this stage of development towns in western countries follow the type of planned city regularly. b. Radial road pattern of concentric (radial concentric system). The design of the road use this fortification pattern appears to anticipate the progress of weapons and war tactics. The road pattern is predominantly see in Europe, can not be see in Asia. c. System-shaped road pattern rectangular lattice or grid (rectangular or grid system). In this system, the city is divided into rectangular blocks and streets parallel to form a right angle.

An important component of cities is their street and road networks. These networks can be thought of as a simplified schematic view of cities, which captures a large part of their structure and organization (Southworth M, 2013). and contains a large amount of information about underlying and universal mechanisms at play in their formation and evolution. Extracting common patterns between cities is a way towards the identification of these underlying mechanisms. At stake is the question of the processes behind the so-called 'organic' patterns - which grow in response to local constraints - and whether they are preferable to the planned patterns which are designed under large-scale constraints (Haggett P, 1969)

City block is a fundamental element of the physical structure of urban forms. Town and cities have generally been laid out in relatively simple patterns of streets and blocks, both in planned and unplanned settlements. Therefore, it can be expected that the properties of different sized, shapes and arrangements of blocks would be well known with documented (Siksna, 1997).

The street network or roads is an important aspect of cities and contains crucial information about their organization and evolution. Characterizing and comparing various street networks could then be helpful for a better understanding of the mechanisms governing the formation and evolution of these systems. For understanding characteristic of the roads is not easy. Simple tools for classify planar networks and most of the measures developed for complex networks are not useful when space is relevant (Barthelemy,2015).

Roads and block patterns become an important element for known the physical structure of urban form and urban morphology and crucial information configuration of the city. Beside that urban structure described by the building coverage ratio (BCR), floor area ratio (FAR), and canyon (H/W) not only give affects for the microclimate but also the location of the building (Paramita and Suparta, 2019). So in this paper the identification of patterns and characteristics of urban morphology is done by using only one indicators namely road and block patterns.

\subsection{Bengkulu City}

Bengkulu City is one of the colonial cities of the former British and Dutch colonies which until now its legacy can be found in the city of Bengkulu, especially the old city of Bengkulu. The old city of Bengkulu was an area in Bengkulu which was used as a trading center in the 16-18th century and built a fort called Fort Marlborough as its center of defense.

The British began to build the city of Bengkulu starting in 1719. As the British colonial authorities to form and design the city of Bengkulu with a good and unique. In addition, the UK also adopted the form of cities with different characteristics in each city under their control. As the ruler at that time the British placed Bengkulu city based on its function, namely the city whose economy was focused on shipping and trade. The focus of this city arrangement adjusts to the location of Bengkulu city which is located along the coast. 


\subsection{Singapore City}

The geographical position of Singapore to the south of the Malay Peninsula is a country in the form of a small island on the Malacca Peninsula. Astronomically at latitude 1 ' 15 "LU1 '26" LU and longitude 103 '40 "BT-104'BT. The area of this country is $818 \mathrm{~km} 2$ with 54 islands around it.

Singapore's national borders are

- North: Johor Strait

- East: South China Sea

- South: Singapore Strait

- West: Malacca Strait

Modern Singapore occurred in 1819 by Sir Stamford Raffles, at that time he established a port for the colonies from England. Under British colonial rule. Singapore has turned into a very strategic port, given its location in the middle of the trade route between India and China which has finally become one of the most important ports in the world to this day. Raffles arrived in Singapore on January 29, 1819. He encountered a small Malay village at the mouth of the Singapore River, chaired by a Temenggung Johor. Because of the abundant fresh water at that time, Raffles made the place for his colonists to live. After signing the agreement on February 6 of the same year, Raffles left the settlement, and handed over responsibility to Colonel William Farquhar and at the end of May, Raffles returned, because of the rapid development of the city, he realized the need for a formal urban plan to guide physical expansion. Then Raffles went back and in October 1822 Raffles returned to Singapore and formed a City Committee led by Lieutenant Philip Jackson to formulate a formal plan for the colony which came to be known as the Jackson Plan, namely by laying the foundations of city roads and Zonal layout. For example, the allocation of civic institutions on the north bank of the Singapore river and creating a major commercial area that came to be known as "Commercial Square" and on the southern edge developed into civic and CBD districts on both sides of the river in a grid pattern. While the settlement zone is in China town, Little India, and Kampong Glam, which can attract the attention of tourists. But the city committee plan led by Jackson only lasted eight years because of the rapidly growing population and severe population density, eventually many residents moved to the suburbs of eastern Singapore. This growth also caused suburban roads to become congested with traffic, especially along Geylang Road which leads to the East Coast.

In 1927 the government tried to capture the situation by establishing the Singapore Improvement Trust (SIT) with the main objective of reducing urban congestion and the provision and improvement of public infrastructure, particularly in widening roads to accommodate and modernize traffic. Their efforts are only in the local area, because they do not have legislative power to produce comprehensive plans or to control urban development. And because the Second World War caused disruption in efforts to reduce the problems of the city, this lasted for 1941-1945. In 1947 the SIT effort did not succeed in overcoming the overcrowding in Singapore. And under the auspices of the ruling People's Action Party at the time, the SIT (Singapore Improvement Trust) was replaced by the HDB (Housing Development Board) which was founded in 1960. This proved to be Singapore's turning point in dealing with population density. HBD has built 5000 housing units that have been built in a span of more than 20 years. In the 1970s, a large proportion of the population had found adequate housing. Most of the current urban planning policies originate from the HDB practices. And Singapore's Regional and municipal planning policies are under the Urban Redevelopment Authority which is to create independent cities and districts that are served 
by regional centers that have their respective functions. The purpose of urban plans is to maximize land use efficiently but comfortably and to serve as many residents as possible with their respective functions, such as infrastructure, environmental preservation, space for water catchment and land for military use all require consideration and national urban planners.

\section{METHODOLOGY}

Kuntowijoyo (2003) revealed that the morphological approach can be explored with synchronic and diachronic. Synchronic study emphasis on observation and analysis of morphological elements to know the city shape at one time. This assessment is generally used to evaluate the present layout of city to problems solve the spatial existing. Studies in diachronic emphasis on observation and analysis of the elements of the morphology of a city from time to time (Kuntowijoyo, 2003). These studies see at the process of development of a city or region from the beginning until nowday. Besides used as the basis for the evaluation of the problems and designing the layout, the diachronic viewpoint will produce a history of the city development and the processes that occur therein, and the result is an expression of the city identity.

To represent morphology or geomorphology of elements and objects in a region can be done through cartography or map (Gomis and Turon, 2018). Using qualitative methods, the research technique is carried out by analyzing data archives originating from the old maps of Bengkulu and Singapore, observations and evaluating detailed aspects including road patterns and blocks. All of them are intended to identify patterns and characteristics of the old cities of Bengkulu and Singapore (see Table 1).

\section{Data analysis process scheme}

Table 1.

\begin{tabular}{|l|l|l|l|}
\hline \multicolumn{1}{|c|}{ Target } & \multicolumn{1}{|c|}{ Analysis of : } & $\begin{array}{l}\text { Analysis } \\
\text { Techniques } \\
\text { Obtained }\end{array}$ \\
\hline $\begin{array}{l}\text { Identify the pattern } \\
\text { and characteristics } \\
\text { urban morphological } \\
\text { of the old city of } \\
\begin{array}{l}\text { Bengkulu and the old } \\
\text { city of Singapore }\end{array}\end{array}$ & $\begin{array}{l}\text { Detailed } \\
\text { Analysis } \\
\text { patterns and block }\end{array}$ & $\begin{array}{l}\text { Diacronic } \\
\text { reading and } \\
\text { morphological } \\
\text { typologies and } \\
\text { figure-ground } \\
\text { techniques }\end{array}$ & $\begin{array}{l}\text { Get patterns } \\
\text { and characteristics } \\
\text { urban morphology } \\
\text { of the old city of } \\
\text { Bengkulu and the } \\
\text { old city of } \\
\text { Singapore } \\
\text { Knowing the } \\
\text { similarities and } \\
\text { differences urban } \\
\text { morphological two } \\
\text { between the two } \\
\text { citys. }\end{array}$ \\
\hline
\end{tabular}

Source: Wardhani, 2019. 


\section{RESULTS AND DISCUSSIONS}

This study is to identify the patterns and morphological characteristics of the city, namely the old city of Bengkulu and the old city of Singapore. The two cities have a historical background in which the two cities are the result of the London Treaty Exchange exchange between England and the Netherlands. In the beginning Bengkulu was formed by the British then switched to forming and developing Singapore. This comparative study begins by analyzing the detailed identification of the patterns of roads and blocks. Identification is done by using diachronic reading and morphological typography analysis techniques. From the identification results it is expected to get similarities and differences in patterns and characteristics of the morphology of the two cities, namely between the old city of Bengkulu and the old city of Singapore (Whardhani, 2019).

\subsection{Patterns and Characteristics Urban Morphological of Bengkulu Old City}

Identification of road and block patterns, by using diachronic reading, typomorphology and figure ground analysis techniques

The pattern of roads and blocks is the second identification carried out to determine the pattern and morphological characteristics of the old city of Bengkulu. The analysis is done using figure ground analysis. This analysis is used to identify road and block patterns by looking at the texture and patterns of an urban fabric.

Identification of the city morphology is done by using the figure / ground analysis technique, it can be known the pattern of existing roads and blocks by looking at the existing ones and historical information of the past. This analysis is carried out on the map of the city of Bengkulu in 1867-208 (see Table 2). Then it will be known the changes and characteristics of the existing road and block patterns in the old city area.

Table 2.

Analysis road and block patterns.

\begin{tabular}{|c|c|c|}
\hline No & Map & Identification \\
\hline 1. & Road and block patterns in 1894 & $\begin{array}{l}\text { Based on the figure ground analysis, it } \\
\text { can be seen that the pattern of the road is }\end{array}$ \\
\hline & PETA BENGKL & $\begin{array}{l}\text { the most ideal form for the city, because } \\
\text { it can develop into all direction and has } \\
\text { balanced, as the advantages. } \\
\text { Besides that, the pattern of roads and } \\
\text { mass blocks formed in } 1894 \text { is a } \\
\text { concentric radial pattern. The old city of } \\
\text { Bengkulu is a city formed by the British } \\
\text { as a place for trade and defense that } \\
\text { focusing the city on the fort area. }\end{array}$ \\
\hline
\end{tabular}



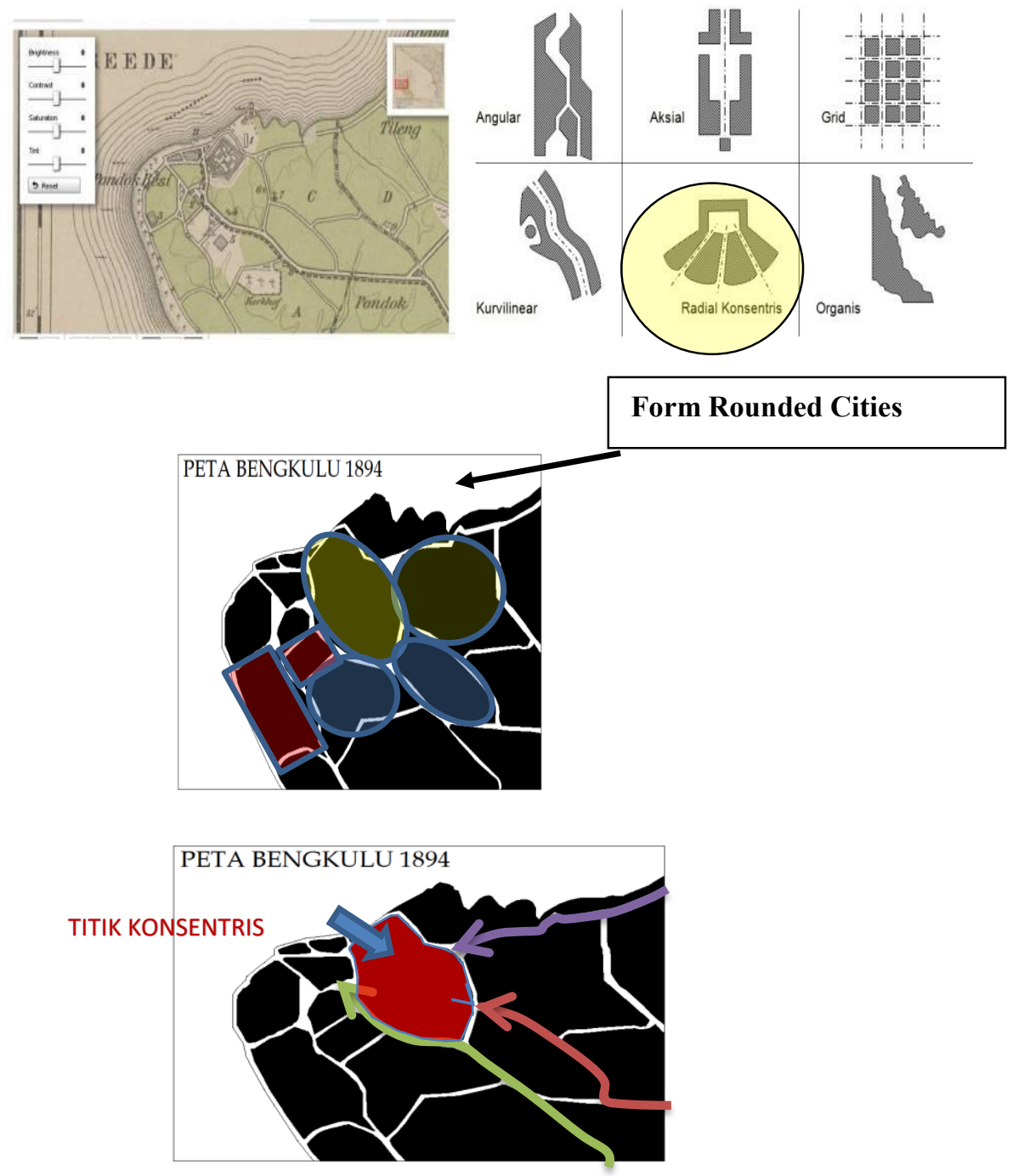
2. Road and Block Patterns in 1914
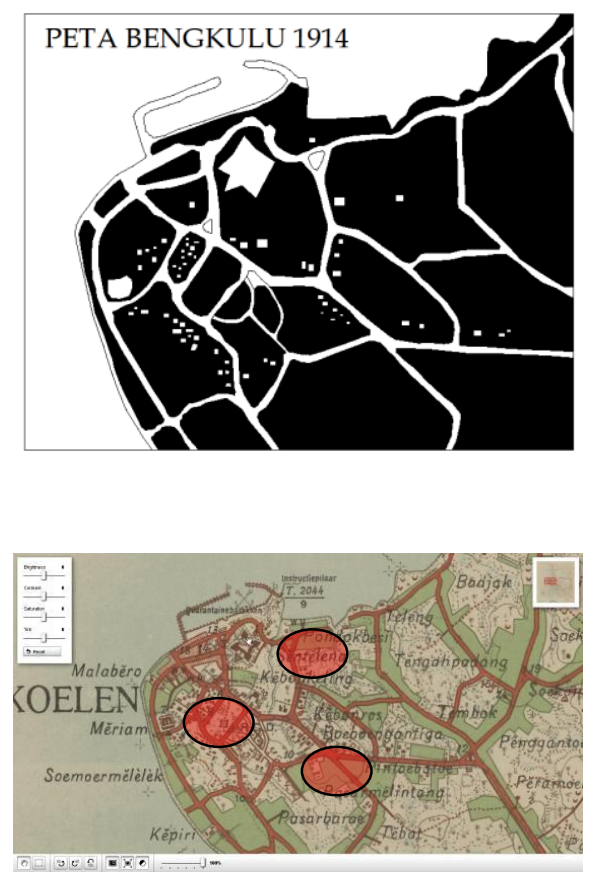

In 1914, the road and block patterns were still the same but the distribution of mass blocks were growth and there were several additional roads, but the pattern and initial shape of the road was still maintained. Radial concentric patterns have been changed. The wider distribution of the mass made current pattern tends to be heterogeneous.

The center of Bengkulu city in British colonial period was located on the beach, so it was called the coastal city which emphasized its social economy on shipping and trade. The City Center was designed to have three main node arrangement patterns that confirm the city center. The road pattern forms the city into a form of constellation (constellation) a series of city blocks that almost have the same size in close proximity. The road pattern produced by this area in the colonial era is homogeneous, where there is only one road arrangement pattern.

In 1924, The pattern of mass distribution has become wider and denser. The main road pattern is still maintained but the mass distribution is increasingly widespread. 


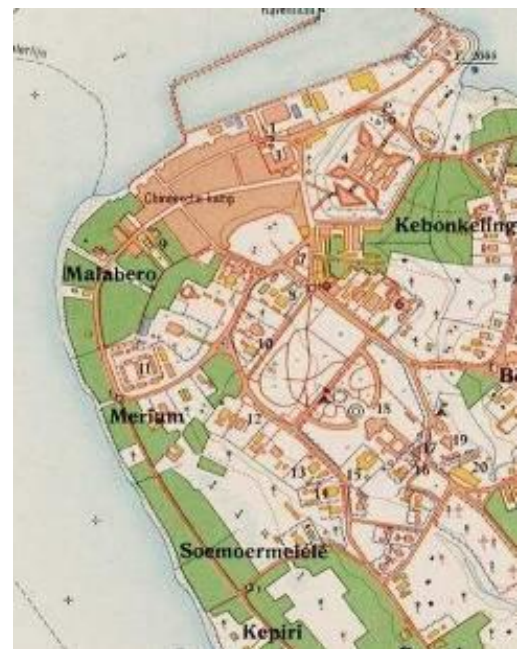

4.
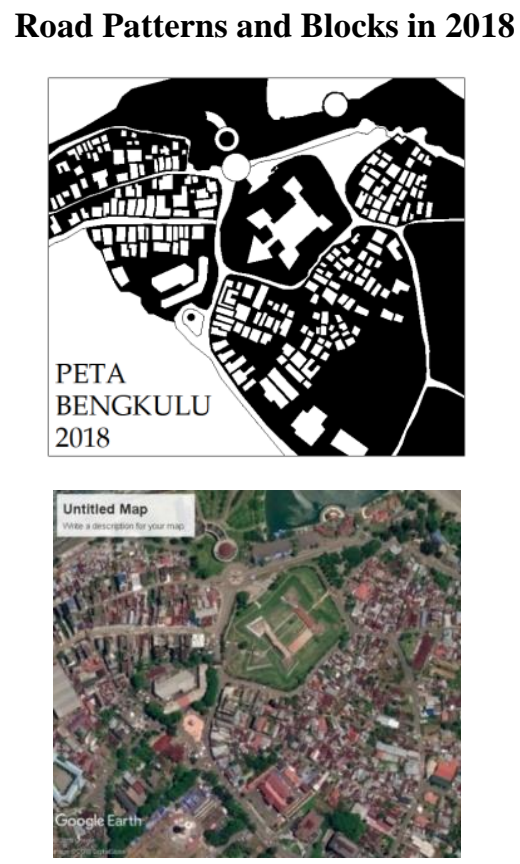

Radial concentric patterns have shifted not to the fortress anymore. This is because the growth of the city and the spread of the masses are expanding to the south.
At this time after the Independence of Bengkulu there were many changes. If Bengkulu city development used to be on the beach, but now the development of the Bengkulu city moves in the direction of the north and west of the city, no longer on the beach. This is marked by the relocation of the city center in an area known as the Suprapto area which is the current trade and government area. The Urban Patterns no longer follow the pattern of British heritage where the main path is to use north-south oriented linear pattern. Resettlement blocks are no longer in the form of concentration. The composition of the area becomes increasingly complex. No longer homogeneous but now heterogeneous, where two or more patterns colliding because the influence of building masses and higher building density.

So based on the analysis of road and block patterns it can be concluded that in the early 1800 s the pattern of roads and rounded cities (round) and radials concentric centered on the fortress area as a center of defense and trade later in its development the form was abandoned where the pattern of roads and blocks becoming increasingly complex and heterogeneous and the trade and government center has shifted towards the middle of the city of Bengkulu while the fortress area has been abandoned and turned into a tourist attraction for cultural heritage and beaches. 


\subsection{Patterns and characteristics urban morphological the old city of Singapore}

\section{Identification of road and block patterns, typo-morphology}

The pattern of roads and blocks is the second identification carried out to determine the pattern and morphological characteristics of the old city of Singapore. The analysis is done using figure ground analysis. This analysis is used to identify road and block patterns by looking at the texture and patterns of an urban fabric.

Identification of the city morphology is done by using the figure / ground analysis technique, it can be known the pattern of existing roads and blocks by looking at the existing ones and historical information of the past (see Table 3). This analysis is carried out on the map of the city of Bengkulu in 1867-208. Then it will be known the changes and characteristics of the existing road and block patterns in the old city area.

Analysis road and block patterns in Singapore.

Table 3.

\begin{tabular}{lll}
\hline No Maps Identification &
\end{tabular}

1.

Map of Singapore, Jackson Plan 1822

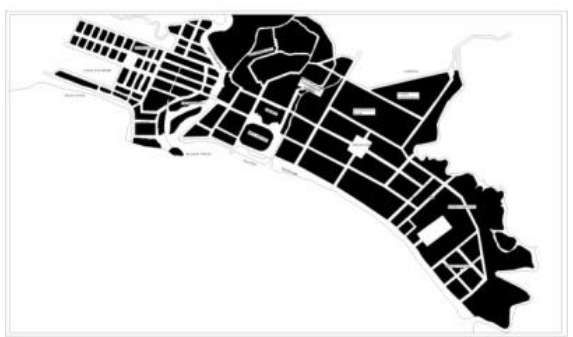

Based on the picture analysis of the ground figure in addition, it can be seen that the road pattern in the form of a grid is the most ideal form for the city, because it has the advantage of being in all directions and balanced.

The formation of the city in 1822 by Jackson was with laying the foundation of city roads and zonal layout, for example the allocation of civil institutions on the north bank of the Singapore river and locating the main commercial areas which became known as the distric civid and CBD on both sides of the river, while the settlement zones are in Chinatown, Little India and Kampong Glams are grouped by race and religion.

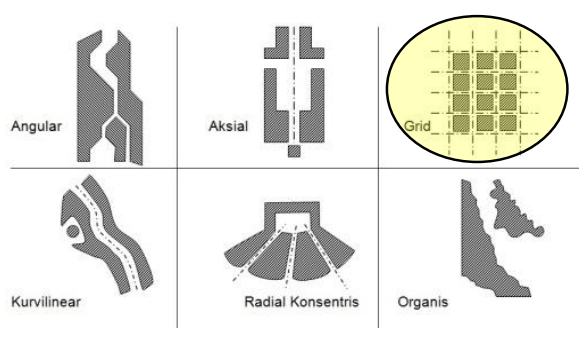




\section{Map of Singapore 1900}

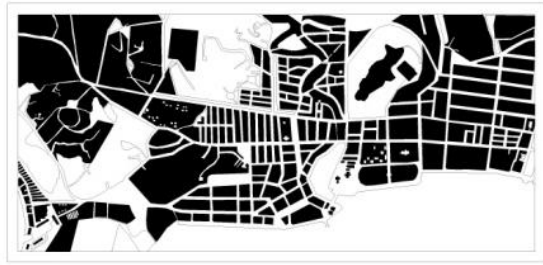

3 Map of Singapore 2019, google earth

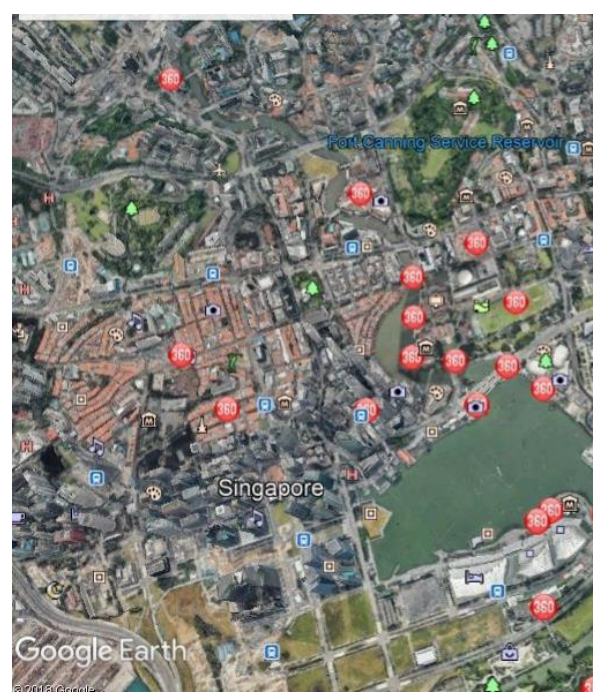

In 1990, the road and block patterns in the old city of Singapore still retained the shape of the grid, but in its development of the city, pattern had experienced impure mixing using grids like the early Jackson Plans again but incorporated curvalinear and radial patterns into urban morphology.

Based on the map image, the old city of Singapore still uses grid patterns like the Jackson plan, but there has been development of road and block patterns.

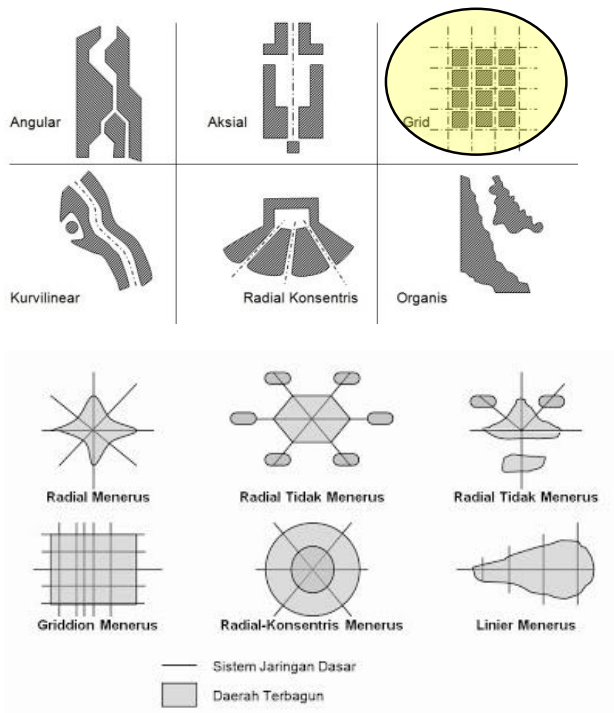

Pola Umum Perkembangan Perkotaan Sumber : Branch, 1996 : 52

www.perencanaankota.blogspot.com

The development is in the form of road patterns and blocks form the city of Singapore forming a satellite city. The form of satellites and new centers (satellite and neighborhood plans), the main city and small cities will be established effective and efficient functional linkages; 


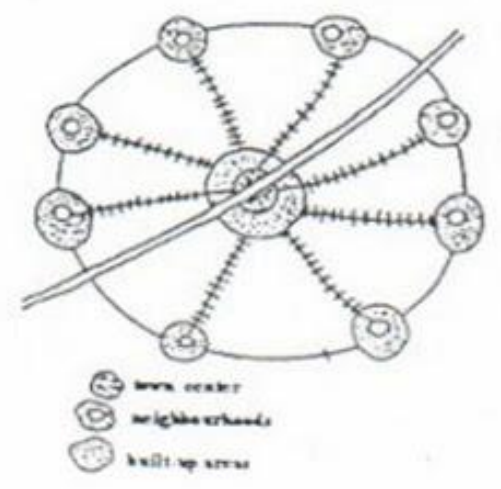

It also forms a stellar or radial. Stellar or radial plans (stellar or radial plans), each tongue is formed a second center of activity that serves to provide services in urban areas and protrudes into the planned as a green line and functions as the lungs of the city, recreation areas and sports areas body for city dwellers.

The development of the city of Singapore did not leave its old city, but synergized with the old city to form the CBD area which remained centered in Marina Bay. The concept of structuring CBD areas in developed countries generally uses a simple pattern of a superblock grid. The central commercial buildings are arranged in such a way that they are squeezed together so that the line is commensurate with only a tight 0 meter. Bangu-nan immediately met the sidewalk next to the skyscraper. Super block pattern besides practical, rapid and unsightly. The purpose of the Singapore city plan is to maximize land use efficiently but comfortably and to serve as many residents as possible with their respective functions, such as, infrastructure, environmental preservation, space for water catchment and land for military use all require consideration and national urban planning.

\section{CONCLUSIONS}

So, based on the above identification it can be concluded that the similarity of patterns and morphological characteristics of the cities of Singapore and Bengkulu are the pattern of roads and blocks used by different British colonies in Bengkulu uses a pattern concentric radial and rounded cities centered in Marlborough Fort while Singapore uses a grid pattern. The city center is equally located in the Port, namely Marina Bay and Fort Marlborough in Bengkulu. But in the development of the city of Singapore City Center is still located in the Marina Bay Area which synergizes with the old City, but the city of Bengkulu left the old city and the city center shifted towards the North and South. 


\section{R E F E R E N C E S}

Barthelemy M. (2015) From path to blocks: New measure for street patterns". Journal Environment and Planning B: Planning and Design, 44.

Conzen, M.R.G. (2003) Morphogenesis, morphological regions and secular human agency in the historic townscape, as exemplified by Ludlow. In Conzen, M.P. (ed.) (2003) Thinking about urban form: papers on urban morphology, 1932-1998 (Lang, Oxford) 116-42

Choi, Eunyoung (2012) Walkability as an Urban Design Problem: Understanding the activity of walking in the urban environment. PhD diss., KTH.

Gomis J., Turon C. (2018) The "Base Map" for Urban Planning: Cartographic Representation as A Fundamental Tool for The Representation of The Town Plan. Geographia Technica, 13 (1), 52-61.

Haggett P., Chorley R.J. (1969) Network analysis in geography. London, UK: Edward Arnold.

Kuntowijoyo (2003) Historical Methodology, PT. Tiara Wacana, Yogyakarta: pp 287 (in Bahasa).

Northam (1975) Urban Geography, Michigan University, Wiley: pp 410.

Paramita B., Suparta W. (2019) Alteration of Urban Microclimate in Bandung, Indonesia based on Urban Morphology. Geographia Technica, 14, Special Issue, 213-220.

Smailes A.E. (1955) Some reflections on the geographical description and analysis of townscapes. Transactions and Papers of the Institute of British Geographers 21, 99-115.

Siksna, Arnis (1997) The effects of block size and form in North American and Australian City Centres. Journal urban morphology I,19-33

Southworth M, Ben-Joseph E. (2013) Streets and the shaping of towns and cities. Washington, DC: Island Press.

Whardhani, Fitrianty (2019) Patterns and characteristics of urban Morphology in the old city of Bengkulu. Journal Architecture and Environment, 18,1. 